\title{
Improvement of river network representation in Africa: application of an approach based on digital elevation data and environmental characteristics
}

\author{
Axel P. Belemtougri ${ }^{1}$, Agnès Ducharne ${ }^{2}$, and Harouna Karambiri ${ }^{1}$ \\ ${ }^{1}$ Laboratoire Eaux HydroSystèmes et Agriculture (LEHSA), Institut International d'Ingénierie de l'Eau et de \\ l'Environnement (2iE), Ouagadougou, Burkina Faso \\ ${ }^{2}$ Milieux Environnementaux, Transferts et Interactions dans les hydrosystèmes et les Sols (METIS), \\ Sorbonne Université, CNRS, EPHE, Paris, France
}

Correspondence: Axel P. Belemtougri (axelbelemtougri@gmail.com)

Published: 16 November 2021

\begin{abstract}
In many continental databases representing rivers across Africa, information on rivers characteristics (length, width, intermittent or perennial) is often incomplete, and small streams are largely underrepresented. Fortunately, the use of topographic information from digital elevation models (DEMs) provides an opportunity to have more detailed information on rivers, particularly small streams in broad areas. A common approach to extract streams from DEM is to consider as a stream all DEM cells that drain at least a certain upstream surface, commonly known as the minimum contributing area $\left(A_{\min }\right)$. This parameter $\left(A_{\min }\right)$ is generally defined uniformly over large areas and this independently of the very variable climate and landscape conditions so that the generated streams have a rather uniform spatial distribution. To address this issue, using a $3^{\prime \prime}$ (approx. $90 \mathrm{~m} \times 90 \mathrm{~m}$ ) DEM of Burkina Faso, the relationship between $A_{\min }$ and the observed drainage density $\left(\mathrm{Dd}_{\mathrm{obs}}\right)$ was established with satisfactory performance $\left(r^{2}=0.86\right)$. In ongoing work, the functional relationship between the observed drainage densities $\left(\mathrm{Dd}_{\mathrm{obs}}\right)$ and environmental variables (lithology, climate, geology, vegetation cover) should allow for the establishment of the relationships between $A_{\min }$ and the environmental variables. This relationship allows for spatially variable $A_{\min }$ values depending on landscape characteristics. Before extracting river networks in Africa, the next step will be to validate or update these relationships in several countries.
\end{abstract}

\section{Introduction}

The accurate representation of river network recently, serves as a decision aid for land managers for efficient monitoring and exploitation of the water resource (Heine et al., 2004; Ouellet Dallaire et al., 2019). Models and many studies of hydrologic processes are sensitive to the accurate representation and density of streams (Yan et al., 2020; Brakebill et al., 2011). However, in many continental databases representing rivers across Africa, information on river's characteristics is often incomplete, and small streams are largely underrepresented (Lehner et al., 2008). National hydrographic databases contain reliable hydrographic information in this sense, either localized or nationwide. However, accessibility to these national hydrographic databases remains difficult in Africa because of the cost required and the reluctance of some countries to share this information.

Fortunately, the exploitation of topographic information from digital elevation models (DEM) provides a major opportunity to obtain detailed river descriptions over large areas (Liu et al., 2005). With the aid of Geographic Information Systems (GIS), river extraction usually involves defining a threshold river pixel number $\left(N_{\mathrm{p}}\right)$ which is a value from which a DEM pixel is considered a river. The upstream area drained by this number of pixels $\left(N_{\mathrm{p}}\right)$ corresponds to minimum contributing area $\left(A_{\min }\right)$ (O'Callaghan and Mark, 1984). A low $A_{\min }$ threshold increases the length of the extracted stream and vice versa. The choice of $A_{\min }$ value, 
therefore, condition the length of extracted rivers and influence the drainage density (Dd) which can be defined as the ratio between the total length of rivers in a watershed and its surface (Horton, 1945). Generally, for stream extraction $A_{\min }$ is defined rather arbitrarily and uniformly over large areas due to lack of information, resulting in the generated streams having a rather uniform spatial distribution and often not corresponding to those observed in the field (Passalacqua et al., 2010; Papageorgaki and Nalbantis, 2017). This is the example of the Hydro1k database (US Geological Survey, 2000) and AQUAMAPS (FAO, 2014), which proposes a mapping of rivers extracted from a 30" (approx. $1 \mathrm{~km} \times 1 \mathrm{~km}$ ) and 15" (approx. $500 \mathrm{~m} \times 500 \mathrm{~m}$ ) DEM for a constant $A_{\min }$ value of 1000 and $100 \mathrm{~km}^{2}$, respectively.

In a natural environment, however, drainage density varies spatially as a function of multiple environmental variables (climate, lithology, slope, vegetation cover) and to capture this variability, there is a need to stress the use of spatially variable $A_{\min }$ (Tucker et al., 2001; Da Ros and Borga, 1997). Recently, Schneider et al. (2017) proposed an approach to generate a series of variable $A_{\min }$ values as a function of environmental variables. These $A_{\min }$ values are calibrated on different landscape types (constituted of the spatial intersection of Lithology, Climate, and Slope) with a $500 \mathrm{~m}$ DEM from HydroSHEDS database to match observed hydrographic information from national hydrographic databases of France and Australia. The calibrated $A_{\min }$ values were extrapolated at the global scale, given the local type of landscape, such as to extract a global hydrographic network, called LCS. Despite satisfactory validation in Brazil and USA against the national hydrographic databases, this LCS network shows difficulties in reproducing very high observed drainage densities (Schneider et al., 2017). The LCS network, for example, partially captures the spatial variability of the drainage density of the national hydrographic network of Burkina Faso, which is probably due to the coarse scale of the lithology layer used.

Based on the methodology used by Schneider et al. (2017), our objective is to use the accuracy of local information collected from national geographic institutes and widely available climatic, landscape, DEM information to establish relationships between the minimum contributing area $\left(A_{\min }\right)$ and environmental variables (lithology, climate, geology, vegetation cover) to constitute a spatial model. A first step in setting up the spatial model is to define a relationship between the observed drainage densities $\left(\mathrm{Dd}_{\mathrm{obs}}\right)$ from a national hydrographic database and calibrated minimum contributing areas $\left(A_{\min }\right)$ in Burkina Faso. The same process is applied in Benin and France to evaluate the effect of the scale of a national hydrographic database in the relationship between $A_{\min }$ and $\mathrm{Dd}_{\mathrm{obs}}$. The second step will be to define relationships between the observed drainage densities $\left(\mathrm{Dd}_{\mathrm{obs}}\right)$ and environmental variables (lithology, climate, geology, vegetation cover), which should ultimately allow us to establish relationships between $A_{\min }$ and the environmental variables. This study covers the first step of the model

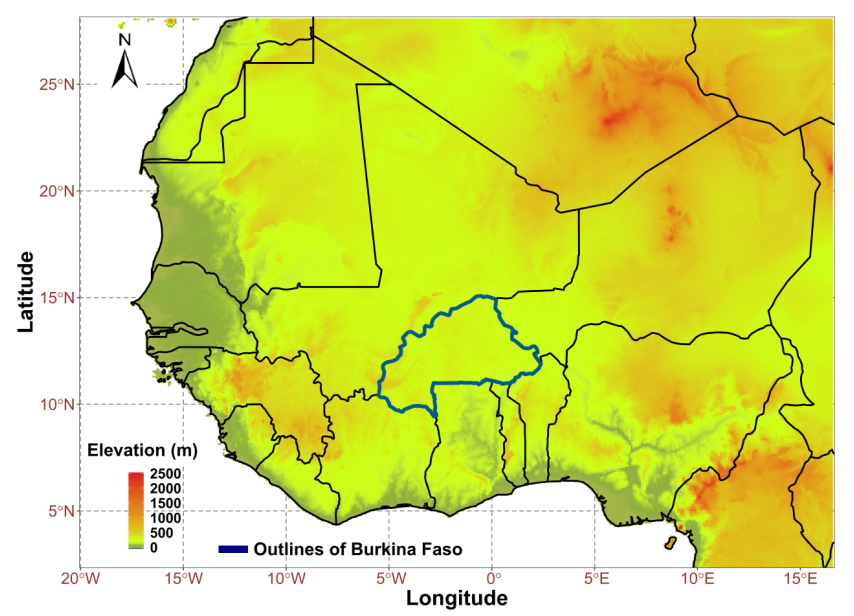

Figure 1. Location of Burkina Faso in West Africa. The borders of the country are shown in dark blue.

calibration in Burkina Faso, and the other steps are ongoing work.

\section{Materials and methods}

\subsection{Study area}

For the first step of the model calibration, we are interested in Burkina Faso, a landlocked country of $274200 \mathrm{~km}^{2}$ located in West Africa and covers quite varied climatic zones with an annual rainfall gradient between South and North (1200 to less than $600 \mathrm{~mm} \mathrm{yr}^{-1}$ respectively) (PANA, 2007). The values of altitudes are mainly between 250 and $350 \mathrm{~m}$, with a maximum altitude around $750 \mathrm{~m}$ making the relief relatively flat (Fig. 1).

\subsection{Description of data}

The DEM used in this study was extracted from the HydroSHEDS database (Lehner et al., 2008), which is the most widely used database currently for hydrological applications at a resolution of $3^{\prime \prime}$ (about $90 \mathrm{~m} \times 90 \mathrm{~m}$ ), i.e. the smallest resolution proposed by the database. The reference hydrographic database (national hydrographic database) taken into account in Burkina-Faso is the BNDT available at the scale of $1: 200000$ and distributed by the IGB (Institut Géographique du Burkina). The reference hydrographic database considered in France and Benin are CARTHAGE and BDI, respectively, available at the same scale of $1: 50000$, and distributed by the IGN (Institut Géographique National) France and IGN Bénin.

\subsection{Methods}

All maps and spatial processing are made using ArcGIS software (10.6.1) and the graphics using $\mathrm{R}$ software ver- 

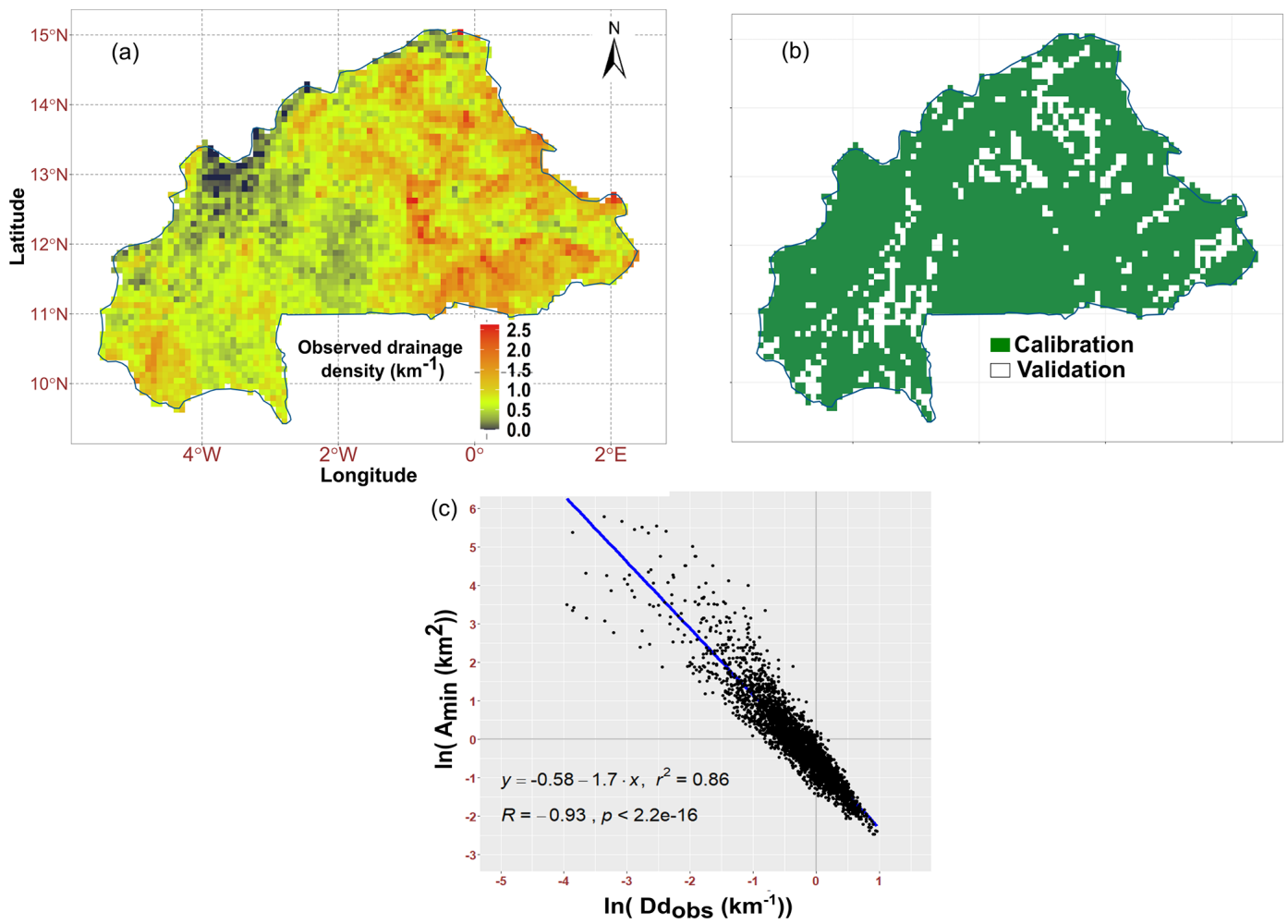

Figure 2. Results of the first stage of model implementation in Burkina Faso. (a) Representation of the observed drainage density in $5^{\prime}$ grid cells. (b) Calibration and validation areas for the relationship between $A_{\min }$ and $\mathrm{Dd}_{\text {obs }}$. (c) Relation between the calibrated values of $A_{\text {min }}$ and $\mathrm{Dd}_{\mathrm{obs}}$ values in $5^{\prime}$ grid cells, with the axes in logarithm.

sion 3.6.1. The ArcGIS tool has been used to extract 400 river networks in Burkina Faso using the DEM from which the direction and accumulation grids are also progressively extracted. To span a large range of drainage densities, the number of pixels defined to extract these networks $\left(N_{\mathrm{p}}\right)$ ranges between 1 to 40000 , corresponding to $A_{\min }$ between $0.0081-$ $324 \mathrm{~km}^{2}$.

The territory of Burkina Faso has been divided into $5^{\prime}$ grid cells (about $64 \mathrm{~km}^{2}$ at the equator) for this analysis. For each of the 400 extracted networks, the drainage density is calculated as the total river length $(\mathrm{km})$ inside a $5^{\prime}$ grid cell, divided by the surface area of the grid cell $\left(\mathrm{km}^{2}\right)$. The same procedure is used to calculate the observed drainage density $\left(\mathrm{Dd}_{\mathrm{obs}}\right)$ using the river network information contained in the reference hydrographic database (BNDT) of Burkina Faso (Fig. 2a). For each grid cell, the calibrated $A_{\min }$ value is the one defining the extracted network (among the 400 possibilities) that best approximates the observed drainage density $\left(\mathrm{Dd}_{\mathrm{obs}}\right)$, based on the BNDT river layer, in this grid cell. Thus, the selected $A_{\min }$ is the one minimizing the difference in drainage density between the extracted networks and the observed BNDT network in the grid cell. We randomly selected several grid cells that were excluded from the calibration process (Fig. 2b) and that represents $14 \%$ of the territory. It is on these grid cells that validation of the relation- ship established between calibrated $A_{\min }$ and $\mathrm{Dd}_{\text {obs }}$ was carried out. The same calibration process was applied in Benin and France to evaluate the effect of the scale of hydrographic database in the relationship between $A_{\min }$ and $\mathrm{Dd}_{\text {obs }}$.

\section{Results and discussions}

The relationship between $A_{\min }$ and $\mathrm{Dd}_{\mathrm{obs}}$, based on the first step spatial model in Burkina, the calibrated values of $A_{\text {min }}$ (Fig. 2c) obtained vary between $0.084-318 \mathrm{~km}^{2}$. The minimum value obtained $\left(0.084 \mathrm{~km}^{2}\right)$ is much lower than those used in the continental databases (Hydrolk and Aquamaps at constant $A_{\min }$ values of 1000 and $100 \mathrm{~km}^{2}$, respectively, LCS with variable values falls between $0.3-193 \mathrm{~km}^{2}$ ). This may reflect consideration of higher drainage densities in Burkina compared to the values obtained from the databases mentioned above, given that the lower $A_{\min }$ becomes, the higher $\operatorname{Dd}_{\text {obs }}$ will.

The results of this first stage of the model implementation allowed us to establish a relationship (Fig. 2c) with very satisfactory performances (coefficient of determination $r^{2}=$ 0.86 , correlation coefficient $R=-0.93, p$ value $<2.2 \times$ $\left.10^{-16}\right)$ :

$$
A_{\min }=0.56 \cdot \mathrm{Dd}_{\mathrm{obs}}^{-1.7}
$$


Table 1. Performance of validation of the first step of the model.

\begin{tabular}{lrc}
\hline Statistical parameters & $\mathrm{Dd}_{\text {obs }}$ & $\mathrm{Dd}_{\text {sim }}$ \\
\hline Mean & 1.01 & 0.99 \\
Standard deviation & 0.42 & 0.41 \\
Correlation coefficient & 1 & 0.93 \\
RMSE (Root Mean Square Error) & 0 & 0.15 \\
\hline
\end{tabular}

Table 2. Relationship between $A_{\min }$ and $\mathrm{Dd}_{\mathrm{obs}}$ in different countries and at different scales.

\begin{tabular}{llccr}
\hline Country & Equations & $r^{2}$ & $R$ & Scale \\
\hline Bénin & $A_{\min }=0.41 \cdot \mathrm{Dd}^{-1.8}$ & 0.88 & -0.94 & $1: 50000$ \\
France & $A_{\min }=0.53 \cdot \mathrm{Dd}^{-1.7}$ & 0.82 & -0.91 & $1: 50000$ \\
Burkina Faso & $A_{\min }=0.56 \cdot \mathrm{Dd}^{-1.7}$ & 0.86 & -0.93 & $1: 200000$ \\
\hline
\end{tabular}

with $A_{\min }\left(\mathrm{km}^{2}\right)$ and $\operatorname{Dd}_{\mathrm{obs}}\left(\mathrm{km}^{-1}\right)$. Equation (1) shows a decrease in the minimum contributing area $\left(A_{\min }\right)$ as a function of an increase in drainage density, in the form of a power relation as mentioned in some studies such as Moglen et al. (1998) and Colombo et al. (2007). It should allow from the observed drainage density to find the corresponding $A_{\min }$, a necessary parameter for stream extraction. Validation of Eq. (1) on the remaining $14 \%$ of the territory (Fig. 2b) allowed us to extract streams with calculated drainage densities $\left(\mathrm{Dd}_{\text {sim }}\right)$ almost similar to those observed $\left(\mathrm{Dd}_{\mathrm{obs}}\right)$, with a correlation coefficient of 0.93 and an RMSE of 0.15 (Table 1).

There is a similarity in the equations between $A_{\min }$ as a function of $\mathrm{Dd}_{\mathrm{obs}}$ at different scales and in different countries with $r^{2}$ performances between 0.82 and 0.86 (Table 2).

Likely, this relationship does not depend on the scale of the hydrographic database. Calibration of the hydrographic database at different scales in other countries would help to confirm this hypothesis.

\section{Conclusions}

This study proposes a method to develop a model of minimum contributing areas $\left(A_{\min }\right)$ as a function of environmental variables (lithology, precipitation, evapotranspiration, runoff, slope, vegetation cover). The first step presented here leads to a very performant relationship between $A_{\text {min }}$ and $\mathrm{Dd}_{\mathrm{obs}}$ in Burkina Faso. This relationship may even be independent from the scale of the hydrographic database. However, this quality needs confirmation by additional calibration tests in other countries with different scales of hydrographic databases. If validated in other countries with different climates, lithology, and drainage density, this first relationship should allow us to locally estimate the best $A_{\min }$ from the observed drainage densities without having to extract 400 different hydrographic networks for example. However, the final goal is to characterize $A_{\min }$ in areas lacking hydrographic information, where observed drainage densities are therefore not available. To this end, we plan to establish a second empirical relationship, linking observed drainage densities and environmental variables. Once calibrated in Burkina Faso, this relationship between $\mathrm{Dd}_{\mathrm{obs}}$ and environmental variables can be combined to the first one between $A_{\text {min }}$ and $\mathrm{Dd}_{\mathrm{obs}}$, such as to directly infer $A_{\min }$ from environmental variables. For validation, we plan to apply this spatial model of $A_{\min }$ to extract the rivers of Benin, Kenya, South Africa, and Madagascar, where hydrographic networks have been collected from national institutes. These countries were chosen because of the ease of access to the data and the different types of climate they cover. Upon satisfactory validation, this two-step spatial model of $A_{\min }$ could be applied to the entire African continent to extract more accurate hydrographic networks than the current continental databases, thus making it possible to support water management in regions where hydrographic observations are missing or limited.

Data availability. DEM data are freely available at https://doi.org/10.1029/2008EO100001 (Lehner et al., 2008). The hydrographic reference networks of Burkina Faso and Bénin are available on request from the agencies (Institut géographique du Burkina Faso - IGB, Institut géographique national du Bénin - IGN Bénin). The hydrographic network of France is freely available on the website: https://www.data.gouv.fr/fr/datasets/ cours-deau-metropole-2016-bd-carthage/ (BD Carthage, 2016).

Author contributions. APB did the conceptualization, methodology, formal analysis, writing - original draft. The co-authors contributed as follows: AD participated in Conceptualization, Methodology, writing - review and editing, supervision; HK participated in conceptualization, methodology, writing - review and editing, supervision.

Competing interests. The contact author has declared that neither they nor their co-authors have any competing interests.

Disclaimer. Publisher's note: Copernicus Publications remains neutral with regard to jurisdictional claims in published maps and institutional affiliations.

Special issue statement. This article is part of the special issue "Hydrology of Large River Basins of Africa". It is a result of the 4th International Conference on the "Hydrology of the Great Rivers of Africa", Cotonou, Benin, 13-20 November 2021.

Financial support. This research has been supported by the African Development Bank Group (project no. P-Z1-IA0-013, grant no. 2100155032824). 


\section{References}

BD Carthage: Cours d'eau - Métropole 2016 available at: https://www.data.gouv.fr/fr/datasets/ cours-deau-metropole-2016-bd-carthage/, last access: 14 April 2021.

Brakebill, J. W., Wolock, D. M., and Terziotti, S.: Digital Hydrologic Networks Supporting Applications Related to Spatially Referenced Regression Modeling 1, J. Am. Water Resour. Assoc., 47, 916-932, 2011.

Colombo, R., Vogt, J. V., Soille, P., Paracchini, M. L., and de Jager, A.: Deriving river networks and catchments at the European scale from medium resolution digital elevation data, Catena, 70, 296305, https://doi.org/10.1016/j.catena.2006.10.001, 2007.

Da Ros, D. and Borga, M.: Use of digital elevation model data for the derivation of the geomorphological instantaneous unit hydrograph, Hydrol. Process., 11, 13-33, 1997.

FAO: AQUAMAPS Global spatial database on water and agriculture, Food and Agriculture Organization of the United Nations, available at: https://data.apps.fao.org/aquamaps/ (last access: 21 April 2021), 2014.

Heine, R. A., Lant, C. L., and Sengupta, R. R.: Development and Comparison of Approaches for Automated Mapping of Stream Channel Networks, Ann. Assoc. Am. Geogr., 94, 477490, https://doi.org/10.1111/j.1467-8306.2004.00409.x, 2004.

Horton, R. E.: Erosional development of streams and their drainage basins; hydrophysical approach to quantitative morphology, Geol. Soc. Am. Bull., 56, 275-370, 1945.

Lehner, B., Verdin, K., and Jarvis, A.: New Global Hydrography Derived From Spaceborne Elevation Data, EOS Trans. Am. Geophys. Union [data set], 89, 93, https://doi.org/10.1029/2008EO100001, 2008.

Liu, X., Peterson, J., and Zhang, Z.: High-resolution DEM generated from LiDAR data for water resource management, in: Proceedings of the International Congress on Modelling and Simulation (MODSIM05), December 2005, Australia, 1402-1408, 2005.

Moglen, G. E., Eltahir, E. A. B., and Bras, R. L.: On the sensitivity of drainage density to climate change, Water Resour. Res., 34, 855-862, https://doi.org/10.1029/97WR02709, 1998.
O'Callaghan, J. F. and Mark, D. M.: The extraction of drainage networks from digital elevation data, Comput. Vis. Graph. Image Process., 28, 323-344, 1984.

Ouellet Dallaire, C., Lehner, B., Sayre, R., and Thieme, M.: A multidisciplinary framework to derive global river reach classifications at high spatial resolution, Environ. Res. Lett., 14, 024003, https://doi.org/10.1088/1748-9326/aad8e9, 2019.

PANA: Programme National d'adaptation de la variabilité et aux changements climatiques, Ministère de l'environnement et du cadre du vie, Burkina Faso, 2007.

Papageorgaki, I. and Nalbantis, I.: Definition of critical support area revisited, European Water, 57, 273-278, 2017.

Passalacqua, P., Do Trung, T., Foufoula-Georgiou, E., Sapiro, G., and Dietrich, W. E.: A geometric framework for channel network extraction from lidar: Nonlinear diffusion and geodesic paths, J. Geophys. Res.-Earth, 115, F01002, https://doi.org/10.1029/2009JF001254, 2010.

Schneider, A., Jost, A., Coulon, C., Silvestre, M., Théry, S., and Ducharne, A.: Global-scale river network extraction based on high-resolution topography and constrained by lithology, climate, slope, and observed drainage density: Global-Scale River Network Extraction, Geophys. Res. Lett., 44, 2773-2781, https://doi.org/10.1002/2016GL071844, 2017.

Tucker, G. E., Catani, F., Rinaldo, A., and Bras, R. L.: Statistical analysis of drainage density from digital terrain data, Geomorphology, 36, 187-202, https://doi.org/10.1016/S0169555X(00)00056-8, 2001.

US Geological Survey: HYDRO1k Elevation Derivative Database, available at: https://www.usgs.gov/centers/eros/science/ usgs-eros-archive-digital-elevation-hydro1k?qt-science

center_objects=0\#qt-science_center_objects (last access: 21 April 2021), 2000.

Yan, Y., Lidberg, W., Tenenbaum, D. E., and Pilesjö, P.: The accuracy of drainage network delineation as a function of environmental factors: A case study in Central and Northern Sweden, Hydrol. Process., 34, 5489-5504, 2020. 